\title{
Human Nature and World Politics: Cognition, Identity, and Influence
}

\author{
Philip E. Tetlock \\ The Ohio State University, \\ Columbus, USA
}

\author{
James M. Goldgeier \\ George Washington University, \\ Washington DC, USA
}

\begin{abstract}
Many psychologists deem it self-evident that psychology can make fundamental contributions to our understanding of world politics Many social scientists however, argue that policymakers are tightly constrained by macro political and economic forces. This article will advance a systemic approach to world politics that challenges: (a) psychologists by highlighting ways in which macro social structures may transform the character of "basic" intrapsychic processes; (b) antipsychological theorists by showing that even the most sweepingly deterministic macro claims - for example, claims about the power of free trade to promote peace - rest on controversial assumptions about human nature. Systemic approaches to world politics are far more consistent with how seasoned diplomats - from Dag Hammarskjöld to Henry Kissinger-have historically approached geopolitical problems than are the traditional but increasingly obsolete micro and macro dualities that have dominated academic analyses.

De nombreux psychologues acceptent d'emblée que la psychologie peut avoir une contribution fondamentale à notre compréhension des politiques mondiales. Cependant de nombreux scientistes sociaux soutennent que les décideurs sont contraints par de puissantes forces macro-politiques et macro-économiques Cet article propose une approche systémique des politiques mondiales qui met au défi: (a) les psychologues en mettant en valeur la manière dont les structures macrosociales transforment la nature de processus intrapsychiques fondamentaux; et (b) les théoriciens anti-psychologiques en montrant que même les positions les plus déterministes, par exemple celles sur l'influence du libre échange dans la promotion de la paix, sont basées sur des postulats discutables sur la nature humaine. Les approches systémiques des politiques mondiales ressemblent davantage à la manière avec laquelle des diplomates expérimentés, de Dag Hammarskjöld à Henry Kissinger, se sont historquement attaqués à des problèmes géopolitiques que les dualismes traditionnels mais de plus en plus dépassés qui ont dominé les analyses académiques.
\end{abstract}

Perhaps it will turn out to be just end-of-the-millennium sensationalism, but there has been a lot of talk recently about our having reached one of those alleged turning points in history. At one end of the opinion spectrum are scholars who suggest that humanity has now reached the end of history-at least if, by history, we mean the chronicle of great power wars-and that violence as a method of resolving intergroup disputes is about to become as obsolete as dueling has become for resolving interpersonal disputes. They justify their optimism by pointing to the extraordinary power of weapons of mass destruction, which make war transparently irrational, and the global spread of democracy and freemarket forms of economic organization, which reduce the likelihood that irrational leaders will wind up with control over weapons of mass destruction (see Fukuyama, 1992; Mueller, 1989). At the other end are those much less sanguine about our collective prospects. These equally thoughtful observers have pointed to the risk of environmental apocalypse (Kennedy, 1993), to the recent flare-ups of nasty ethnopolitical conflicts (Moynihan, 1996), and to the potential for an epidemic of lowintensity warfare and perhaps even for a clash of civilizations (Huntington, 1996). In this view, low-intensity warfare is the outcome we get if we are lucky. If weapons of mass destruction-nuclear or biochemical-slip into the hands of angry and desperate fringe groups, humanity should brace itself for a far worse set of outcomes.

What can psychological science contribute to our understanding of the past, present, and future of world politics? Here again we find a deep division of opinion. In one disciplinary camp, we find advocates of the microreductionist syllogism, which posits that: (a) the policy makers who shape world politics are human beings (as, of course, are the constituencies and mass publics they represent); (b) psychology sheds light on why human beings think, feel, and act as they do; (c) psychology sheds light on why policy makers and other players in

Requests for reprints should be addressed to Philip E. Tetlock, The Ohio State University, 142 Townsend Hall, 1885 Neil Avenue, Columbus, OH 43210, USA (Tel: +1 614292 1571; Fax: +1 614292 5601; E-mail: tetlock.1@osu.edu).

The authors would like to acknowledge the financial assistance of the MacArthur Foundation, the Mershon Center of The Ohio State University, and the University of California's Institute on Global Conflict and Cooperation. 
the political game think, feel, and act as they do. From this standpoint, it is self-evident that psychology can make an important contribution. Note, however, that there is plenty of room for disagreement over exactly what these contributions might be and over what types of psychological propositions we might plug into the micro-reductionist syllogism-the candidates ranging from psychoanalytic theory to behavioural decision theory to theories of intragroup and intergroup dynamics.

Many social scientists, and some policy makers, take umbrage with this approach. They often endorse the mirror-image macro-reductionist syllogism which runs as follows: (a) policy makers are tightly constrained by geopolitical and geoeconomic forces in the international environment and by domestic political forces internal to their societies; (b) neorealist, neo-institutionalist, and game theoretic approaches shed light on these strategic constraints on policy; (c) these same approaches shed light on why policy makers act as they do. Here it is pretty much self-evident that psychology is useless. Note though, once again, there is much room for disagreement over what might be useful: in this case, over what types of security-maximizing or power-maximizing or wealth-maximizing or norm-following logic to insert into the macro syllogism in order to derive testable predictions (cf. Bueno de Mesquita \& Lalman, 1992; Keohane, 1984; Ruggie, 1998; Waltz, 1979).

Each group readily finds evidence to support its approach. Examples of miscalculation in world politics abound, and many of these can be traced to cognitive or motivational biases of the sort that psychologists study, such as over-reliance on low-effort heuristics, groupthink, low thresholds for making invidious in-group/ out-group distinctions, and so forth. Psychologists also cannot help but notice that despite the "obvious" structural constraints pointed to by the international relations scholars, heated debates typically occur within a particular elite as its members attempt to discern the threats and opportunities they face. Hawks and doves in the United States, for example, had sharply diverging views of the nature of the Soviet threat during the Cold War and of the best means to respond to the challenge (R. Osgood, 1981). Meanwhile, international relations scholars point to cases like the Grand Alliance of World War II, when previously bitter foes overcame ideological differences in the face of a common threat, as examples of structurally induced balance-of-power politics that attenuate individual bias (Layne, 1993; Waltz, 1979).

Given what we know about the factors that fuel invidious in-group and out-group stereotyping, we should not be surprised that each camp has formed a less than flattering assessment of the other. The specialists in world politics have somewhat more elaborate stereotypes of psychologists than psychologists have of specialists in world politics. This asymmetry is a natural one, for international relations scholars do spend more time thinking about psychological issues than psychologists spend time thinking about international ones. Many of these international relations specialists view psychologists as politically naive meddlers who just do not understand the hardball rules of elite politics, as amusingly irrelevant bunglers who look for explanations in all the wrong places, as arrogant dilettantes who think they have much to teach but little to learn, and as shrill activists who claim to be advancing science but are really just promoting a partisan agenda under an academic cover.

Psychologists who work in the domain of world politics often form rather jaded impressions of their international-relations colleagues: they seem prone to cognitive hubris, frequently convincing themselves that they can explain the inexplicable and anticipate the unpredictable (Dawes, 1998); they are methodologically naive because they do not appreciate how problematic causal inference is in complex, single-run path-dependent systems; they are oblivious to discoveries that psychologists made long ago and hence are continually rediscovering the wheel and congratulating themselves for it; finally, they are politically reactionary and their "explanations" are often just thinly veiled justifications for the policies of their political patrons.

There may well be kernels of truth to these stereotypes. But stereotypes hardly advance our understanding of world politics. The challenge is how to initiate a serious and sustained conversation across the great divide that separates psychological theory from theories of international relations. A useful starting point is to recognize from the outset that both the micro and macro syllogisms are fatally flawed as guides to designing cumulative and progressive research programmes in world politics (progressive in the Lakatosian, not the political, sense). There is a need for a systemic syllogism which posits that micro and macro levels of analysis are not mutually exclusive but rather hopelessly intertwined. The psychology of elite politics is not just a matter of exporting relevant psychological laws, applying them to well-defined antecedent conditions, and deducing conclusions. This is a mistake - a mistake because it rules out a priori the possibility that the so-called psychological laws might interact in complex ways with political processes that are specific to elite decision making in particular political cultures and institutional settings. Conversely, it is every bit as big a mistake to posit a priori that elite politics is so special that it should be the exclusive explanatory preserve of those who posit the policy process to be constrained by the pure logic of some theoretical ideal type such as the security or power maximizer of realist theories of world politics, or the wealth maximizer of liberal theories of world politics. Although they may occasionally forget the fact, or try to persuade us to forget it, policy makers are still human, all too human.

The core premises of a systemic approach to world politics are integrative: (a) policy makers are human beings who work within a complex matrix of cultural, institutional, political, and economic constraints; (b) 
policy is often the result of processes that are neither purely psychological nor purely political but rather psychopolitical; (c) these psychopolitical processes can be understood only by simultaneously embedding psychological principles in the historical flow of events and grounding our understanding of political processes in realistic assumptions about the workings of the human mind. On the one hand, psychological laws will frequently need to be qualified to capture the subtleties of the political process. On the other hand, the "Great Abstractions" of international relations theory-security or wealth maximization - will need to be qualified by psychological laws that highlight specific ways in which policy makers often stray dramatically from these formulaic versions of rationality. Micro processes shape our perceptions of macro constraints-of how threatening other states are, of how inherently anarchic the international system is, and of the potential for reaching mutually beneficial agreements.

In the remainder of this article, we discuss several examples of how micro and macro factors interpenetrate and can be melded into sturdier systemic principles for understanding world politics. We begin by considering specific ways in which work at a macro level of analysis raises challenges to the applicability of psychological research to world politics, and then we turn to the micro counter-claims to several core macro generalizations. We also note that differences among macro theorists often stem from their different implicit psychological assumptions, further highlighting the need to develop a more integrative approach.

\section{MACRO-LEVEL CHALLENGES TO PSYCHOLOGICAL CLAIMS}

Consider four key psychological claims. First, many psychologists believe that there are widespread and systematic deviations from rationality that are ultimately grounded in fundamental, species-typical, perceptual and cognitive processes (cf. Arkes, 1991). Second, many psychologists argue that response tendencies such as the fundamental attribution error, belief perseverance, and over-confidence represent deviations from wellestablished normative models of judgement and choice (Fiske \& Taylor, 1991; Nisbett \& Ross, 1980). Third, minimal group experiments conducted by psychologists suggest that people have low thresholds for relying on simplistic stereotypes of out-groups, for making invidious in-group/out-group distinctions, and for trying to maximize relative - not absolute or joint-gains (Brewer \& Brown, 1998; Mercer, 1996). Finally, although psychologists recognize that the optimal influence tactic in any given situation is a function of a complex array of cognitive, motivational, and normative moderators (Pruitt, 1998), they have traditionally been wary of policies that emphasize deterrence and threats of force (White, 1984). In each case, there are macro challenges to psychology from theorists who argue that incentives or accountabil- ity checks and balances are sufficient to attenuate biases rooted in individual-level behaviour.

\section{Are Cognitive Biases Robust?}

Many macro theorists are sceptical: they argue that deviations from rationality are likely to be rare in the competitive world of power politics because of domestic political selection mechanisms. Irrational decision makers do not usually rise into high-level roles, and when they do rise into such roles, their influence is checked by accountability mechanisms and the counterinfluence of other, more rational, players in the political system. If neither of these factors suffices and irrational decision makers do have a pronounced impact on national security policy, other players in the international system quickly exploit these mistakes and the original player changes course. In extremely rare cases, the irrational leader persists and suffers severe losses, perhaps to the point of destroying the state and eliminating it from the map as an autonomous entity. The sceptics can also point to several instances in which either psychologists or psychologically minded political scientists have jumped the gun in concluding that cognitive biases had contaminated political decision making (Tetlock, 1998a). Once thought to have been a primary exhibit in the prosecution's case for belief perseverance in elite decision making (Holsti, 1967), John Foster Dulles, US Secretary of State in the 1950s, now appears - on the basis of recently declassified documents - to have held a considerably more nuanced and flexible view of the "communist monolith." He recognized early in the Eisenhower administration the potential for a serious Sino-Soviet split (Gaddis, 1997). In a similar vein, it has been possible to raise challenges to other claims of cognitive bias: decision makers may invoke historical analogies for rhetorical purposes that they know, in private, to be simplistic (e.g. Dean Rusk's defensive quip: "I'm not the village idiot. I know that Ho is not Hitler"). Decision makers may also recognize trade-offs in confidential meetings that they would be loath to acknowledge in public (see review by Tetlock, 1998a).

This debate is, of course, strikingly reminiscent of a disagreement that arises in behavioural economics in which psychologists tend to be optimistic about the generalizability of biases in competitive markets, where biased information processors can be exploited by more rational competitors; meanwhile, some experimental economists are more sceptical and take the view that many biases will be severely attenuated, or even eliminated, when people make decisions in competitive markets with repeated play and receive clear and consequential feedback concerning the consequences of their choices. For example, decision makers who rely on effort-conserving heuristics such as Tversky's eliminationby-aspects that yield intransitive choices (A over B, B over $\mathrm{C}, \mathrm{C}$ over $\mathrm{A}$ ) are at great risk of being transformed into money pumps by arbitrageurs who never tire of exploiting irrationality. There will be no simple resolution to 
this controversy. Initial experimental results, with some noteworthy exceptions (Smith, 1994) seem to favour the psychologists (Camerer, 1995). But there is plenty of room to argue over methodological details and the adequacy of the "de-biasing" tests. Indeed, even if the psychologists do turn out to be right in the current round of controversy, there still lurks long-term possibility that psychological discoveries of irrationality are fated to be self-negating prophecies. The more robust and consequential the deviation from rationality, the greater the temptation among predators to exploit it and the stronger the incentive among decision makers to correct it.

\section{The Classification of Effects as Errors and Biases}

Some macro-oriented social scientists argue that judgemental tendencies which psychologists label as errors or biases in experimental settings can be quite adaptive when placed in a broader societal or political perspective. The fundamental attribution error - the systematic insensitivity of observers to situational explanation s for conductis a case in point. The base rate of opportunistic behaviour in the international system is arguably high, whether we define the opportunists as taking the form of "Saddam Husseins" or currency speculators. The consequences of failing to identify opportunists can be quite severe. Finally, forgiving or relaxed attributional policies-which indicate a willingness to consider situational explanations for policies of other states that injure the interests of one's own state-create incentives for gametheory-style opportunism because they reduce the costs of defection. Given these features of the international system, it may well be prudent for decision makers to communicate that they have a low threshold for making punitive dispositional attributions to other states that act in ways which harm the interests of one's own state. The fundamental attribution error may be neither fundamental nor erroneous in many foreign policy settings.

A potential example of this type of "adaptive" error is the Bush administration's response to Gorbachev's cooperative initiatives. Outsiders criticized both the "strategic pause" announced in 1989 and the general White House attitude that Gorbachev was simply tricking the West into letting its guard down. Many American officials were slow to accept that Soviet policies represented a fundamental redefinition of Soviet interests. Realists would argue, however, that rather than succumbing to error, these officials could not adjust more rapidly because the penalties for being wrong would have been so severe, and in the end the costs of delaying any reciprocation were minimal. After all, the US did conclude strategic arms reduction agreements, ensured that a unified Germany remained a full member of NATO, and helped to manage a peaceful transition to a postSoviet world (cf. Wohlforth, 1997).

Other "biases" may also be quite functional in certain respects. Consider the numerous case-study, longitudinal, and experimental demonstrations of over-confidence, the tendency of even many seasoned professionals motivated to find the right answer to exaggerate the likelihood of their predictions being on target (Jervis, 1976; Tetlock, 1998b, 1999). One could concede the empirical claims of previous studies but still insist that there is a good case, at another level of analysis, that over-confidence can be a useful negotiation strategy for convincing adversaries that one is indeed firm and an effective leadership strategy for inspiring confidence in wavering subordinates. In a similar vein, notwithstanding the impressive evidence that political professionals are often too slow to change their minds by rigorous Bayesian standards (Tetlock, 1998b), there is a good case that "irrational" belief perseverance can often be adaptive in an international environment where the diagnosticity of new evidence is typically politically contentious and the costs of changing course can be politically steep, splintering precarious coalitions and re-igniting old rivalries. Or, turning to sunk-cost effects, it may be economically irrational, but politically rational, to escalate commitments to losing causes when the mass public has an implicit theory of leadership which stipulates that strong leaders do not acknowledge mistakes or abandon commitments. US elites generated strong initial support for stepped-up involvement in Vietnam in 1965 and only came to abandon the commitment when the domestic-political costs of remaining there became prohibitively steep. Even then, negotiating an "honourable" withdrawal remained a central objective of the Nixon administration - so central that, 25 years later, key decision makers from that administration continued to maintain that they had succeeded in negotiating an honourable peace (a settlement that was sabotaged by short-sighted opponents in the aftermath of Watergate).

\section{Are People Inherently Tribal?}

Some international-relations scholars, especially neorealists, resonate to the rather gloomy, Hobbesian, portrait of human nature that emerges from minimal group experiments (Mercer, 1996). But they can explain relative-gains maximization without any resort to micro processes, noting simply that security maximizers under anarchy must always be on guard for enemies. Furthermore, they doubt that psychological processes at the mass level are more than epiphenomenal byproducts of manipulation by opportunistic elites whofrom Machiavelli to Milosevic - have long viewed "dizzying giddy minds with foreign quarrels" as an expeditious means of advancing their own influence in the state and their state's influence in the international system.

Other international-relation s scholars, especially neoinstitutionalists, argue that macro-level processes can actually attenuate in-group/out-group bias. They note that: (a) the shadow of the future reins in our worst impulses toward out-groups (we may be psychologically 
predisposed to treat them unfairly but we fear what will happen when the out-group has an opportunity to retaliate, as is, of course, the case in repeated-play games-Oye, 1986); (b) the reputation costs of acting unfairly toward out-groups can be steep (there are no purely bilateral relationships outside the psychological laboratory and people are sometimes willing to make material sacrifices to punish those who violate norms of distributive and procedural justice); (c) nations-unlike laboratory groups-are differentiated into subgroups, some of which often have strong interests in establishing and maintaining good relations with out-groups, for example to accrue benefits from trade (Haas, 1958).

In short, some international-relation s scholars accept the functional relationships documented by psychologists but doubt that they play a key causal role in world politics; others argue that the functional relationships identified by psychologists will be sharply circumscribed by institutional structures and constraints of international politics.

\section{When Do Classic Diplomatic Influence Tactics-Coercion, Deterrence, Reassurance, Appeals to Fairness, Invocation of Third Parties, Side- payments, and Supplication-Work?}

Psychologists are typically sympathetic to policies of reassurance that stress the need to establish conciliatory atmospherics and the preconditions for each side acquiring a more accurate understanding of the other, for example, the approach known as Graduated and Reciprocated Initiatives in Tension Reduction (Larson, 1987, 1997; C. Osgood, 1962) and the proliferation of conflictresolution workshops (Kelman \& Cohen, 1976). Many psychologists are of the view that the fixed-pie fallacy is widespread (Thompson, 1994) and that people chronically underestimate the potential for arriving at mutually beneficial agreements because they often get sucked into self-perpetuating conflict spirals (White, 1984). This world view is quite Hammarskjöldian in spirit: it implies that thoughtful diplomacy can play a critical role both in preventing conflicts and in bringing ongoing conflicts to an earlier end (Vance \& Hamburg, 1997).

Many neorealists and deterrence theorists view this psychological approach as extraordinarily naive. Policies of reassurance often just set one's state up for continued exploitation. Credible, properly calibrated, threats are the most effective way of preventing aggression in an anarchic environment in which (in contrast to Robert Axelrod's tournaments) losing just one round can be fatal. In this view, when deterrence fails, the failure should most often be attributed to improper implementation, especially efforts at sending out complex mixedsignal messages that are easy to misinterpret. By contrast, deterrence successes are largely invisible, hence we should expect a lot of ingratitude: sceptics will challenge counterfactual claims of the form "but for our strong deterrence posture, aggression would have occurred"
(Achen \& Snidal, 1989; Huth \& Russett, 1990; Lebow \& Stein, 1990).

Game theorists of an Axelrodian persuasion are less inclined to be dismissive of the conflict-reduction proposals of authors such as Charles Osgood, Robert White, and Herbert Kelman. Even here, however, we find a harder edge to the policy recommendations than is typically found in the psychological literature. For example, Axelrod argues that tit-for-tat works as well as it does because it is nice (it never defects first), clear (transparent and easy to understand), forgiving (when the other side stops defecting, so does one's own state), and retaliatory (it is triggered by a single act of defection and it continues to retaliate until the other side relents). Some psychologists worry that tit-for-tat is too harsh and punitive and propose kinder and gentler variants of tit-fortat. These include allowing the other side to defect two or more times in a row before retaliating, or initiating a cooperative move to try to escape from a potentially never-ending cycle of retaliation and counter-retaliation. These differences in perspective can be traced to disagreements over both facts and values. Advocates of harder-line policies suspect that there are more predatory states in the international environment that stand ready to take advantage of unilateral cooperation and they deem it a more serious mistake to fail to identify a predator correctly than it is to mislabel a non-hostile state as predatory.

\section{POTENTIAL QUALIFICATIONS TO INFLUENTIAL MACRO CLAIMS}

Thus far, we have concentrated on ways in which structures and constraints in world politics may amplify or attenuate well-established psychological laws and generalizations. We now reverse the focus and consider ways in which properties of human nature may moderate the applicability of four influential macro generalizations and laws: first, that balancing is a fundamental law of world politics (Waltz, 1979); second, that free trade promotes peace by linking states into webs of mutually beneficial interdependence and by creating domestic interest groups who oppose beggar-thy-neighbour policies that jeopardize those trade ties (Rosecrance, 1986); third, that democracies do not go to war with one another because politicians subject to rule-constraints at home are more likely to follow rule-constraints internationally (Doyle, 1983); and fourth, that economically rational states will create transnational institutions that promote joint gains (Keohane, 1984).

These macro generalizations rest on the minimal assumptions about human nature made by realist and liberal traditions in international relations. Realists assume individuals (and the states they populate) to be preoccupied with self-preservation and/or power, operating within a self-help anarchic environment that forces states to balance opposing power and ensures that sustained cooperation is difficult. Whether we observe war 
or peace is a function of the distribution of capabilities (bipolar vs. multipolar; changing vs. stable; offence vs. defence dominant) and sometimes due to the properties of states (status quo vs. revisionist). In the starkly realist world, alliances dissolve after victory; institutions collapse after the powerful state that created them declines.

For the liberals, individuals are wealth rather than power or security maximizers. In the economic institutionalist variant, theorists conjoin the goal of wealth maximization with patterns of economic interdependency within global markets; for political liberals, the pursuit of gain occurs within the constraints of political competition within domestic societies. Variation in the environment is defined by the degree of economic or political competition (free trade vs. mercantilism; democracy vs. authoritarianism). In this world, established institutions will outlast hegemonic decline because states come to recognize their value in promoting absolute gains and democratic, market-oriented states will create a zone of peace and prosperity.

Each of these theoretical traditions can get its hypothetico-deductive apparatus working through its characterization of the strategic environment. No heroic assumptions of human nature are necessary. The individual who finds himself in Hobbes' state of nature or Smith's free market acts in accordance with the structure of power or degree of market competition. Do the generalizations that flow from these minimalist assumptions really hold, and in what ways do psychological processes serve as moderating or mediating variables?

\section{Does Free Trade Promote Peace?}

Now, psychologists are in the position of saying "not so fast." Market economies create winners and losers. Whereas the Smithian view is that absolute gains are clearly a virtue since everyone is better off, social psychologists note that trade can also create numerous opportunities for hostile stereotypes to flourish ("they" are benefiting more than we are; "they" are cheating - closing their markets to us or engaging in predatory pricing or exploiting their workers or allowing businesses to escape environmental-protection regulations).

Negative assessments of globalization are certainly not new. Some structuralists have noted, for example, that one response to perceptions of relative deprivation is counterproductive elite behaviour. Historically, elites in the periphery have sought to match the consumption patterns of elites in the more advanced states. This behaviour can siphon off capital from more productive uses, thereby inducing persistent underdevelopment, which may in turn create conflict (Janos, 1986). From a psychological point of view, we should expect trade to promote peace only when it stimulates cooperative equal-status contact and forms of accountability that interfere with intergroup accentuation and in-group favouritism.

\section{Why Do Democracies So Rarely Fight Each Other?}

Liberal peace theorists have emphasized both structural and normative factors to explain this phenomenon. Popularly based governments are more selective in the human and material costs they are willing to bear than autocratic regimes because a public that has a voice can punish reckless leaders at the polls. Liberals have also argued that common values lead to greater willingness to accommodate fellow liberals, and these values may be reinforced by robust international institutions (Doyle, 1983; Moravcsik, 1997).

Rather than focusing on the effects of political structures, psychologists are likely to be more curious about the mediating micro mechanisms that produce the rather robust democratic peace findings of the 20th century. Here they might invoke two arguments: (a) pluralistic and democratic polities are inherently more complex stimuli (hence it is less plausible for demagogues to claim that "they" are all alike); (b) it is more difficult in open societies for demagogues to mobilize hatred towards out-groups because accountability checks and balances compel at least limited recognition of the legitimacy of the claims of the other side. One recent political science study (Owen, 1997) demonstrates that liberal elites must recognize other states as liberal for the democratic peace argument to hold, and these perceptions rest on views of what kinds of institutional arrangements make their own state liberal. Apparent anomalies to the democratic-peace argument, such as the US decision to go to war with Spain in 1898, stem from a failure by one side to view the other as liberal, regardless of whether scholars would characterize a state as democratic or not.

\section{The Origins and Maintenance of Transnational Institutions}

Some structuralists argue simply that powerful hegemons create institutions that serve their interests (Gilpin, 1981). But a now standard neo-institutionalis t claim is that such institutions can be maintained after the hegemon's decline and can even arise without a hegemon whenever the shadow of the future looms large, and whenever the transaction costs of relying on case-by-case, bilateral negotiations are prohibitively steep (Keohane, 1984; Keohane \& Martin, 1995). In short, in this view, transnational institutions arise whenever it is economically rational to create them. Psychologists are likely to be sceptical and to view this neo-institutionalist claim as simultaneously too restrictive and too expansive. The claim is too restrictive because regimes can arise via other mechanisms aside from transaction-cost calculations-e.g. shared norms of fairness or the desire to punish free riders. The claim is too expansive because actors may fail to form regimes even when all of the neo-institutionalists' preconditions 
are met (shared mindsets may blind actors to the feasibility or benefits of coordination).

Another issue is whether states can maintain international institutions when cheating becomes attractive. At one end of the opinion continuum are internationalrelations scholars who respond with a categorical "no"; they argue that states use norms of fair play merely as rhetorical cloaks for self-interest. As Thucydides suggested, the strong do what they will, and the weak accept what they must; therefore, in the realist account, institutions can at most coerce grudging compliance. Neoinstitutionalists are divided. States often have high thresholds for defecting from international regimes because of the reputation costs. But if defection is sufficiently tempting, and if the state is sufficiently powerful, we should expect a painful process of re-negotiating the original ground rules to accommodate the powerful state (Baldwin, 1993). At the other end of the continuum are the constructivists, who believe that decision makers can really come to believe in the principles and values underlying transnational agreements and institutions (Finnemore, 1996). Acts that once might have seemed legitimate assertions of national self-interest-e.g. torturing or killing POWs, the use of chemical weapons, expropriating property - might now seem to be unthinkable breaches of fundamental standards of decency and fair play (Katzenstein, 1996).

A long-standing debate in the social psychological literature parallels that in the international-relation s literature. The most Machiavellian versions of impression management theory maintain that the "attitude change" observed by dissonance and self-perception theorists in forced compliance experiments are really just forms of public posturing and have gone to some ingenious methodological lengths to prove the point (Tetlock \& Manstead, 1985) - up to and including persuading research participants that the experimenter possesses an infallible lie detector that it would be foolhardy to try to deceive. The balance of the evidence, however, favours the view that some genuine internalization of counterattitudinal behaviour does occur reliably and repeatedly. Most psychologists would probably agree that most political actors (psychopaths excluded) will gradually internalize the norms of fair play implicit in international institutions. These norms can become functionally autonomous from the interests that may once have inspired them. This internalization process should be especially true in democracies, in which leaders must justify departures from widely held norms of fair play to a variety of constituencies.

A contribution of psychologists is to delineate the conditions under which decision makers are especially likely to change their underlying attitudes to bring them into line with initially counter-attitudinal behavior. Cognitive dissonance and self-perception research using forced-compliance paradigms suggests, for example, that decision makers are especially likely to internalize attitudes consistent with their behaviour when they believe they have some elements of free choice. It is critical here that the external pressure for compliance not be too heavy-handed; otherwise people will attribute their behaviour to external demands rather than internal values or attitudes. As good diplomats have long known, heavy-handed pressure tactics often backfire and, even when they do work, the effects are often fleeting.

\section{Is Balancing a Fundamental Law of World Politics?}

Many neorealists offer an unequivocal "yes": states are rational, self-preserving actors in an anarchic, selfhelp environment in which there are no reliable lawenforcement mechanisms. Whenever states see another state becoming too powerful, and threatening to dominate the entire system, they coalesce against it, thereby thwarting it. It is no accident, in this view, that Napoleon and Hitler failed. They were fated to fail by the most fundamental law of world politics.

Psychologists would tend to argue that this argument seriously overestimates the rationality of key players. Often subject to wishful thinking, leaders may be too slow to recognize an emerging hegemonic threat (the critique often aimed at advocates of appeasement in the 1930s), and states may opt to bandwagon instead of balance in response to attractive offers from wouldbe hegemons (Schweller, 1997). Signalling emerges as a huge problem for states seeking to deter challengers to the status quo; although rationalists might argue that this is merely a failure of implementation, psychologists have demonstrated persistent, systematic biases that inhibit effective balancing (Jervis, 1976, 1989). Psychologists would also argue that neorealist advocates of balancing have seriously underestimated the role of chance in small-sample data sets. It may well be that we have just been "lucky" that would-be hegemons have failed.

\section{CAN BOUNDARY CONDITIONS CHANGE?}

Central to the macro-level debate in international relations is the question of mutability of the structures and processes that constrain interstate behaviour. Is world politics inherently anarchic or will some form of cohesive international social order eventually emerge? Here we find sharp divisions among the macro theorists (Katzenstein, 1996). Traditional realists and modern neorealists affirm the anarchic character of world politics (everything else is rhetorical illusion); as long as no global authority exists that possesses a monopoly on the legitimate use of force, states will be highly constrained in the type of cooperation they can pursue. But neo-institutionalists and sociological constructivists believe that, as the density of cross-border transactions rise, more and more powerful international regulatory bodies will inevitably arise (Ruggie, 1986, 1998). 
Most psychologists are likely to be more optimistic than the neorealists and less optimistic than the neoinstitutionalists and constructivists. The primacy of ethnicity and nationalism as bases for intergroup distinctions may indeed gradually erode with the expansion of cooperative, equal-status contact (trade and travel) and the creation of transnational institutions that serve superordinate goals (the need to generate global public goods may include controlling weapons of mass destruction or financial contagions or greenhouse effects or biological epidemics or crafting rules for civil aviation). But the process is reversible by events-perceived slights, insults, assassinations, economic shocks, demagogic exhortations - that reactivate old loyalties.

Moreover, transnational institutions will be effective in the long-term only insofar as they acquire legitimacy in the eyes of the attentive publics in key states by establishing a reputation for procedural justice (Tyler \& Smith, 1998). Achieving this is difficult, in part, because of cognitive biases (scrupulously even-handed mediators will still often be perceived by partisans from both sides as biased in favour of the other side) and, in part, for political reasons (domestic political opponents of international institutions can play on these cognitive biases and mobilize substantial resistance to continued participation in the institution). If nothing else, the difficulty of the task is underscored by the problems that successful transnational institutions-such as the International Committee of the Red Cross, the European Union, the World Trade Organization - have had to surmount in legitimizing themselves in the eyes of a wide range of nations.

\section{CONCLUDING REMARKS}

Critics of psychological explanations of world politics have had two legitimate grounds for complaint: too often psychologists have been guilty of either reductionist dilettantism or of simplistic activism. Neither objection vitiates the enterprise of seeking to ground our understanding of world politics in psychological processes but the objections do call attention to embarrassing shortcomings in previous work.

Although we have offered our own warnings against "psychological reductionism," it is equally important to recognize the perils of "macro reductionism"- -sweepingly simplistic rejections of all forms of psychological explanation. Many macro-level objections to psychology are undercut by theoretical debates within the international relations community that turn out, on close inspection, to pivot around competing psychological assumptions. Consider three illustrative controversies: (1) the debates over balancing; (2) the rationality of democratic control of foreign policy; (3) the root causes of the democratic peace:

1. Although many scholars attribute rational balancing behaviour to the pressure imposed by the anarchy of world politics (there is no central authority to impose order in world politics), they disagree about the optimal distribution of capabilities. For the neorealists, a bipolar world of the sort that existed in the Cold War is most stable because one merely has to balance the one other superpower, whereas multipolar systems are more uncertain (who are potential enemies?) and thus are more likely to produce miscalculation and inadvertent war (Layne, 1993; Mearsheimer, 1990; Waltz, 1979). Multipolarity induces cognitive overload by increasing the number of possible enemies and coalitions that might form against one's state. For other scholars, however, multipolarity is just as obviously more stable than bipolarity. Gearing up for armed conflict with another state requires mobilizing mass and elite opinion. More states in the system diminish the attention one can give to each state and thus diffuses the tension that exists in any given relationship (K.W. Deutsch \& Singer, 1964). A superficially purely structuralist debate thus hinges on competing psychological models of how decision makers respond to environments of varying polarity.

2. The debate regarding whether democracy attenuates or exacerbates bias rests in part on a debate about rationality. For many realists, democratic politics exacerbate irrationality because popular pressure can force elites away from an "objective" analysis of their strategic environment. Gaining public support for foreign policy strategies often requires using overblown rhetoric to galvanize key constituencies. Nuances of conceptually complex policies such as containment or detente are quickly sacrificed (Christensen, 1996; Kennan, 1993; Kissinger, 1964). For liberals, however, the checks and balances of democratic accountability can constrain a leader from making hasty or emotional decisions about war and peace, or can rein in leaders who have initiated unpopular wars (Doyle, 1983). For realists, rational leaders will respond correctly to objective strategic factors but can get thrown off course by irrational publics. For liberals, irrational leaders will be prevented from damaging decisions due to accountability to publics attuned to the personal costs they might be forced to bear either in blood or treasure.

3. Constructivist critiques of realism also use psychological arguments to build their explanations. The basic argument is that whether states see themselves as locked in a zero-sum game with another derives not from the distribution of material capabilities in the system but rather from the processes of interaction among states. States interact within a given social structure, which shape how they define their identity and their interests, that is, who they think they are and what they think they want. This interaction then helps reshape the social structure. This "intersubjective" process determines whether states will respond to others in this system in a cooperative, competitive, or indifferent manner (Wendt, 1992, 1994). Although these arguments often start at the macro level of social structure, they utilize micro processes to underpin their explanations (Finnemore \& Sikkink, 1998; Katzenstein, 1996). For example, Thomas 
Risse-Kappen's (1995) argument that the democratic peace is socially constructed rests on the use of attribution theory. Leaders attribute cooperative behaviour emanating from fellow liberal states as due to a predisposition resulting from their democratic institutions (rather than due to structural constraints, as cognitiveconsistency theory would suggest in gauging an enemy's accommodation). This dispositional attribution leads to trust, reduces security dilemmas, and reinforces the initial presumption regarding the other state's predisposition. The "social construction" that becomes a "structural" feature was triggered by a psychological process.

Ironically, then, the value of incorporating psychological variables into models of international relations is demonstrated by the arguments made by the macrolevel theorists who downplay them. Indeed, the buzzwords that dominate major works in the neorealist, neoliberal, and constructivist traditions today are perceptions, ideas, and identity (cf. Goldstein \& Keohane, 1993; Katzenstein, 1996; Walt, 1996). Yet these works explicitly fail to address the psychological dimensions of these variables. Typically, the reason is that a concern with developing a comprehensive theory of international politics leads scholars to focus on structural regularities in the international system and the resulting general patterns of interstate behaviour.

So where does this discussion leave us? Wary though we are of psychological reductionism, we see a vastly greater role for psychological explanations than is customarily acknowledged among specialists in world politics. The core problem is two-fold: psychologists generally underestimate the subtlety and complexity of the task of adapting psychological concepts to world politics whereas international-relations scholars generally overestimate their ability to craft compelling explanations that dispense altogether with psychology.

\section{REFERENCES}

Achen, C.H., \& Snidal, D. (1989). Rational deterrence theory and comparative case studies. World Politics, 41, 143-169.

Arkes, H. (1991). Costs and benefits of judgment errors: Implications for debiasing. Psychological Bulletin, 110, 486-498.

Axelrod, R.M. (1984). The evolution of cooperation. New York: Basic Books.

Baldwin, D.A. (1993). Neorealism and neoliberalism: The contemporary debate. New York: Columbia University Press.

Breslauer, G.W., \& Tetlock, P.E. (Eds.). (1991). Learning in U.S. and Soviet foreign policy. Boulder, CO: Westview.

Brewer, M.B., \& Brown, R.J. (1996). Intergroup relations. In D.T. Gilbert, S.T. Fiske, \& G. Lindzey (Eds.), Handbook of social psychology. New York: McGraw-Hill.

Bueno de Mesquita, \& Lalman, D. (1992). War and reason. New Haven, CT: Yale University Press.

Camerer, C. (1995). Individual decision making. In J.H. Hagel \& A.E. Roth (Eds.), The handbook of experimental economics (pp. 587-704). Princeton, NJ: Princeton University Press.

Christensen, T.J. (1996). Useful adversaries: Grand strategy, domestic mobilization, and Sino-American conflict, 19471958. Princeton, NJ: Princeton University Press.
Dawes, R.M. (1998). Behavioural decision making and judgment. In D.T. Gilbert, S.T. Fiske, \& G. Lindzey (Eds.), The handbook of social psychology, Vol. 1 (4th ed., pp. 497-548). New York: McGraw-Hill.

Deutsch, K.W., \& Singer, J.D. (1964). Multipolar power systems and international stability. World Politics, 16, 390-406.

Deutsch, M. (1983). The prevention of World War III: A psychological perspective. Political Psychology, 4, 3-31.

Downs, G.W. (1991). Arms races and war. In P.E. Tetlock, R. Jervis, P. Stern, J.L. Husbands, \& C. Tilly (Eds.), Behavior, society, nuclear war, Vol. 2 (pp. 73-109). New York: Oxford University Press.

Doyle, M. W. (1983). Kant, liberal legacies, and foreign affairs. Parts 1 and 2. Philosophy and Public Affairs, 12, 205-254, 323-353.

Druckman, D., \& Hopmann, P.T. (1989). Behavioural aspects of international negotiation. In P.E. Tetlock, R. Jervis, P. Stern, J.L. Husbands, \& C. Tilly (Eds.), Behaviour, society, nuclear war, Vol. 1 (pp. 85-173). New York: Oxford University Press.

Finnemore, M. (1996). National interests in international society. Ithaca, NJ: Cornell University Press.

Finnemore, M., \& Sikkink, K. (1998). International norm dynamics and political change. International Organization, $52,887-917$.

Fiske, S., \& Taylor, S. (1991). Social cognition. New York: McGraw-Hill.

Fukuyama, F. (1992). The end of history and the last man. Toronto: Maxwell MacMillan.

Gaddis, J.L. (1997). We now know: Rethinking cold war history. Oxford: Oxford University Press.

George, A.L. (1980). Presidential decision making in foreign policy: The effective use of information and advice. Boulder, CO: Westview.

George, A.L. (1993). Bridging the gap: Theory and practice in foreign policy. Washington, DC: US Institute of Peace.

Goldstein, J., \& Keohane, R.O. (Eds.). (1993). Ideas and foreign policy: Beliefs, institutions, and political change. Ithaca, NJ: Cornell University Press.

Haas, E.B. (1958). The uniting of Europe: Political, social, and economic forces, 1950-57. Stanford, CA: Stanford University Press.

Holsti, O.R. (1967). Cognitive dynamics and images of the enemy. In R. Fagan (Ed.), Enemies of politics (pp. 25-96). Chicago: Rand McNally.

Huth, P., \& Russett, B. (1990). Testing deterrence theory: Rigor makes a difference. World Politics, 42, 466-501.

Janos, A.C. (1986). Politics and paradigms: Changing theories of change in social science. Stanford, CA: Stanford University Press.

Jervis, R. (1976). Perception and misperception in international politics. Princeton, NJ: Princeton University Press.

Jervis, R. (1989). The logic of images in international relations. New York: Columbia University Press.

Jervis, R. (1992). The future of international politics: Will it resemble the past? International Security, 16, 39-73.

Kahneman, D., \& Tversky, A. (1979). Prospect theory: An analysis of decision under risk. Econometrica , 47, 263-291.

Katzenstein, P. J. (Ed.). (1996). The culture of national security: Norms and identity in world politics. New York: Columbia University Press.

Kelman, H.C., \& Bloom, A. (1973). Assumptive frameworks in international politics. In J. Knutson (Ed.), Handbook of political psychology (pp. 261-295). San Francisco, CA: Jossey-Bass.

Kelman, H.C., \& Cohen, S.P. (1976). The problem-solving workshop: A social-psychology contribution to the resolution of international conflicts. Journal of Peace Research, 12, 79-90.

Kennan, G.F. (1993). Around the cragged hill. New York: Norton. 
Kennedy, P. (1993). Preparing for the twenty-first century. New York: Random House.

Keohane, R.O. (1984). After hegemony. New York: Columbia University Press.

Keohane, R.O., \& Martin, L.L. (1995). The promise of institutionalist theory. International Security, 20, 39-51.

Khong, Y.F. (1991). Analogies at war. Princeton, NJ: Princeton University Press.

Kissinger, H.A. (1964). A world restored. New York: Grosset \& Dunlap.

Larson, D.W. (1987). Crisis prevention and the Austrian State Treaty. International Organization, 41, 27-60.

Larson, D. W. (1997). Anatomy of mistrust: US-Soviet relations during the Cold War. Ithaca, NJ: Cornell University Press.

Layne, C. (1993). The unipolar illusion: Why new great powers will rise. International Security, 17, 5-51.

Lebow, R.N. (1981). Between peace and war. Baltimore, MD: Johns Hopkins University Press

Lebow, R.N., \& Stein, J.G. (1990). Deterrence: The elusive dependent variable. World Politics, 42, 336-369.

Mack, J. (1985). Toward a collective psychopathology of the nuclear arms competition. Political Psychology, 6, 291-321.

Mearsheimer, J.J. (1990). Back to the future: Instability in Europe after the cold war. International Security, 15, 5-56.

Moravcsik, A. (1997). Taking preferences seriously. A liberal theory of international politics International Organization, 51, 513-553.

Mueller, J. (1989). Retreat from doomsday: The obsolescence of major way. New York: Basic Books.

Oneal, J., Oneal, F., Maoz, Z., \& Russett, B. (1996). The liberal peace: Interdependence, democracy, and international conflict, 1950-1985. Journal of Peace Research, 33, 11-28.

Osgood, R.E. (1981). Containment, Soviet behavior, and grand strategy. Berkeley, CA: Institute of International Studies.

Owen, J.M. (1997). Liberal peace, liberal war: American politics and international security. Ithaca, NY: Cornell University Press.

Oye, K.A. (Ed.). (1986). Cooperation under anarchy. Princeton, NJ: Princeton University Press.

Pruitt, D. (1998). Social conflict. In D. Gilbert, S. Fiske, \& G. Lindzey (Eds.), Handbook of social psychology (pp. XXXX). New York: McGraw Hill.

Risse-Kappen, T. (1995). Democratic peace-warlike democracies? A social constructivist interpretation of the liberal argument. European Journal of International Relations, 1, 491-517.

Rosecrance, R. (1986). The rise of the trading state. New York: Basic Books.

Ross, L., \& Griffin, D. (1991). Subjective construal, social inference, and human misunderstanding In M. Zanna (Ed.), Advances in experimental social psychology, Vol. 24 (pp. 319-359). New York: Academic Press.

Rouhana, N.N., \& Kelman, H.C. (1994). Non-official interaction processes in the resolution of international conflicts: Promoting joint Israeli-Palestinian thinking through a continuing workshop. Journal of Social Issues, 50, 157-178.

Ruggie, J.G. (1986). Continuity and transformation in the world polity: Toward a neorealist synthesis. In R.O. Keohane (Ed.), Neorealism and its critics (pp. 131-157). New York: Columbia University Press.

Ruggie, J.G. (1998). What makes the world hang together?
Neo-utilitarianism and the social constructivist challenge. International Organization, 52, 855-885.

Russett, B. (1996). Counterfactuals and the democratic-peace hypothesis. In P. Tetlock \& A. Belkin (Eds.), Counterfactual thought experiments in world politics (pp. 161-176). Princeton, NJ: Princeton University Press.

Schweller, R.L. (1997). New realist research on alliances: Refining, not refuting, Waltz's balancing proposition. American Political Science Review, 91, 927-930.

Stein, J. (1991). Deterrence and reassurance. In P.E. Tetlock, R. Jervis, P. Stern, J.L. Husbands, \& C. Tilly (Eds.), Behavior, society, nuclear war, Vol. 2 (pp. 8-72). New York: Oxford University Press.

Suedfeld, P. (1992). Cognitive managers and their critics. Political Psychology, 13, 435-453.

Tetlock, P.E. (1979). Identifying victims of groupthink from public statements of decision makers. Journal of Personality and Social Psychology, 37, 1314-1324.

Tetlock, P.E. (1986). Psychological advice on foreign policy: What do we have to contribute? American Psychologist, 41, 557-567.

Tetlock, P. E. (1998a). Social psychology and world politics In S. Fiske, D. Gilbert, \& G. Lindzey (Eds.), Handbook of social psychology (4th ed., pp. 867-912). New York: McGraw-Hill.

Tetlock, P.E. (1998b). Close-call counterfactuals and belief system defenses: I was not almost wrong but I was almost right. Journal of Personality and Social Psychology, 75, 639-652.

Tetlock, P.E. (1999). Theory-driven reasoning about possible pasts and probable futures: Are we prisoners of our preconceptions? American Journal of Political Science, 125, 255-275.

Tetlock, P.E., \& Manstead, A.S.R. (1985). Impression management versus intrapsychic explanations in social psychology: A useful dichotomy? Psychological Review, 92, 58-79.

Tyler, T., \& Smith, H. (1998). Social justice and social movements. In D. Gilbert, S. Fiske, \& G. Lindzey (Eds.), Handbook of social psychology (4th ed., pp. 595-632). New York: McGraw Hill.

Vance, C., \& Hamburg, D. (1997). Pathfinders for peace. Washington, DC: Carnegie Commission on Preventing Deadly Conflict.

Walt, S.M. (1996). Revolution and war. Ithaca, NJ: Cornell University Press.

Waltz, K.N. (1979). Theory of international politics. Reading, MA: Addison-Wesley.

Wendt, A. (1992). Anarchy is what states make of it: The social construction of power politics International Organization, $46,391-425$.

Wendt, A. (1994). Collective identity formation and the international state. American Political Science Review, 88, 384-396.

White, R.K. (1991b). Empathizing with Saddam Hussein. Political Psychology, 12, 291-308.

Winter, D.G. (1992). Personality and foreign policy: Historical overview of research. In E. Singer \& V. Hudson (Eds.), Political psychology and foreign policy (pp. 79-101). Boulder, CO: Westview.

Wohlforth, W.C. (Ed.). (1997). Witnesses to the end of the Cold War. Baltimore, MD: Johns Hopkins University Press. 